\title{
EM TORNO DO ROMANCE DE 30
}

A década de 1930 tem sido considerada, desde sempre e até os dias de hoje, como a "era do romance" no Brasil. Naquele período - marcado por inquietação política, mudanças na economia e na sociedade, novas atitudes estéticas e reflexões pioneiras sobre a realidade nacional - , dando continuidade aos ímpetos de transformação do decênio anterior, mas também em franca polêmica com as proposições modernistas, despontaram alguns dos nossos maiores e mais conhecidos escritores de ficção. $O$ romance de 30 foi muitas vezes descrito como uma experiência estética despreocupada da arte. Ou como expressão de um regionalismo que ficou restrito, se não ao simples pitoresco, à mera denúncia social. A manutenção de uma tal visão chapada daquele que foi um dos períodos mais ricos da ficção brasileira simplesmente se desmancha depois da leitura dos artigos reunidos neste número da Teresa.

Para compreender a diversidade e a complexidade do "romance de 30", o melhor caminho, conforme enfatiza Alfredo Bosi (USP) no texto de abertura, é acrescentar às visões de conjunto o estudo particularizado de autores e obras. Essa combinação de olhares, resultando numa perspectiva ampla e ao mesmo tempo pormenorizada, é justamente o que se propõe aqui, nesta reunião de ensaios que ora versam sobre romances específicos, ora discutem questões de caráter literário ou histórico, que dizem respeito a toda a produção da época. Os colaboradores da revista pertencem a instituições e origens diversas, tendo boa parte deles participado do colóquio "Em torno do romance de 30", organizado pelos professores Ivan Marques, Ricardo Souza de Carvalho e Simone Rossinetti Rufinoni e realizado em maio de 2010 pelo Programa de Pós-Graduação em Literatura Brasileira da USP.

"Caixa de surpresas" é a expressão empregada por Alfredo Bosi para definir a vasta produção literária da década de 30. Nesta edição da Teresa, a exploração começa por Parque industrial, de Patrícia Galvão. Para além do seu conteúdo político imediato, Kenneth David Jackson (Yale University) faz uma abordagem original desse romance ainda pouco analisado, considerando-o como uma continuação de Pauliceia desvairada, o livro emblemático de 1922, e como equivalente literário da pintura modernista de temática urbana.

A presença de Mário de Andrade é invocada em mais dois artigos. Os juízos do escritor paulista sobre a "extraordinária floração" de livros da década de 30 são apresentados e discutidos por Marcos Antonio de Moraes (USP), com base em extenso levantamento das percepções do crítico, registradas em sua produção jornalística, correspondência e marginalia, acerca das obras de Rachel de Queiroz, José Lins do Rego, Erico Verissimo e Jorge Amado, entre outros. Embora tenha constatado, ao final da década, que essa "fase de furiosa produtividade" não Ihe permitia 
a fixação de uma "síntese crítica", Mário escreveria no começo dos anos 40 o ensaio "A elegia de abril", do qual parte Ivan Marques (USP) para considerar a figura do fracassado - e do intelectual fracassado - num arco amplo que inclui José Lins do Rego, Cyro dos Anjos e Graciliano Ramos, até voltar para o Macunaíma e provocar um curto-circuito entre a obra de Mário de Andrade e o romance de 30.

Nos dois estudos seguintes, focaliza-se a literatura de Erico Verissimo. A partir da análise de Caminhos cruzados, Marcos Scheffel (UFRJ) mostra como a reflexão sobre a condição precária do intelectual e seus dilemas em face da realidade brasileira foram temas recorrentes na obra do escritor gaúcho. Já o ensaio de Maria da Glória Bordini (UFRGS) sublinha a importância da técnica do contraponto para a construção, em seus primeiros romances, de uma forma literária não apenas sensível aos ritmos e deslocamentos da cidade moderna, mas também capaz de fazer um corte transversal na sociedade gaúcha, tornando-se, portanto, veículo privilegiado de um olhar crítico que era comum a toda a geração de 30.

O perfil do intelectual militante, que não faz distinção entre a literatura e a política, é examinado por Eduardo de Assis Duarte (UFMG) em seu artigo sobre Jorge Amado, enfocado não a partir de seu trabalho de romancista, mas sim de sua experiência muito menos conhecida de cronista. Ao tratar de um conjunto de crônicas sobre a Segunda Guerra publicadas entre 1942 e 1944, o crítico encontra o intelectual orgânico que desliza do escritor "informativo", papel que previsivelmente assumiria o cronista, para o "operante", ou seja, aquele efetivamente engajado. As relações entre literatura e política também estão no centro do artigo de Thiago Mio Salla, que procura esmiuçar a maneira pela qual uma certa intelectualidade alinhada ao Estado Novo criou um discurso e uma visada crítica que procuravam enquadrar o romance de 30 e o modernismo de 22 como formas legitimadoras do regime de Getúlio Vargas. Mas termina mostrando, por meio da figura emblemática de Graciliano Ramos, que esse esforço redundou em fracasso.

Com sua contundente negatividade, a obra de Graciliano, tal como a dos melhores escritores do período, não ficaria presa nas malhas do ideário estadonovista. É o que mostra Fabio Cesar Alves (USP) no ensaio "Graciliano e a nata da malandragem", que trata da reconstrução, feita pelo autor das Memórias do Cárcere, do seu convívio com bandidos na Colônia Correcional da Ilha Grande. Graças ao aprendizado da dinâmica da marginalidade, o escritor alagoano pôde descortinar as falsas promessas da ideologia trabalhista de Vargas, ao mesmo tempo em que se voltava contra as ilusões do projeto nacional concebido na fase heroica do modernismo. Outro estudo da obra de Graciliano Ramos é oferecido por Luís Bueno (UFPR) em "A presença do amor em Vidas secas", que em meio às agruras da família de retirantes flagra a existência, não enfatizada pelo pessimismo do autor, de desejos, sentimentos e afetos, aos quais se liga a sua própria esperança de sobrevivência. 
O último bloco de ensaios (ou surpresas), além de tratar de um dos temas cruciantes da década de 30 - a decadência do mundo rural e os percalços da modernização conservadora, denunciados de Norte a Sul do país - , põe em evidência a mescla de dimensões sociais e psicológicas que, de acordo com Alfredo Bosi, se faz presente em cada um dos romances, para além das rotineiras classificações. Juliana Santini (UNESP), numa abordagem tão rica quanto imprevista, eleva o humor a elemento capaz de amalgamar crítica social e análise psicológica em Fogo Morto, de José Lins do Rego. Marlí Tereza Furtado (UFPA) coloca em relevo a obra fundamental de Dalcídio Jurandir por meio da análise de seus dois primeiros romances, Chove nos Campos de Cachoeira e Marajó, que, embora publicados apenas em 1941 e 1947, foram escritos durante a década de 1930, período, aliás, em que o autor participou intensamente, como crítico, do debate literário. À semelhança dos nordestinos, o romancista marajoara também se dedica à representação de mundos decadentes e heróis fracassados, enriquecendo a prosa regionalista com os recursos da linguagem e da interiorização.

Luiz Roncari (USP) faz entrelaçar, na produção de Lúcia Miguel Pereira, a crítica e a ficcionista. Para isso analisa seu último romance, Cabra cega, incursão, provavelmente inspirada em Machado de Assis, no universo da "casa velha" e em seu processo ruinoso. Fechando a série de ensaios, Simone Rossinetti Rufinoni (USP) identifica na prosa introspectiva e nos ambientes nebulosos de Cornélio Penna uma apreensão estética da decadência da sociedade patriarcal. Em sua cuidadosa análise de Fronteira, a ensaísta mostra como dois elementos aparentemente desencontrados, o pormenor e a dissipação, constroem uma visão do Brasil como um país no ar, em suspensão: lugar da dissolução que indica não só a incompletude do presente como também a ausência de uma definição positiva para o futuro.

Dando sequência à série de entrevistas com professores de literatura brasileira no exterior, Antonio Dimas (USP) conversa com Randal Johnson, professor da University of California, Los Angeles (UCLA). Pesquisador da literatura e do cinema produzidos no Brasil, autor de obras fundamentais sobre o Cinema Novo e adaptações como Macunaíma, Randal Johnson também se dedica à literatura da década de 30 e estuda, atualmente, a rede de relações sociais e políticas mantidas por Mário de Andrade e Graciliano Ramos, entre outros escritores da época.

A seção de resenhas também se localiza, ela toda, em torno do romance de 30 e atesta o interesse renovado por essa produção. As duas primeiras colaborações tratam de fontes primárias relevantes do período. Artigos, entrevistas e depoimentos de Graciliano Ramos, recolhidos nos volumes Cangaços e Conversas, são abordados na resenha de Jean Pierre Chauvin (USP). Já a correspondência de Cyro dos Anjos e Carlos Drummond de Andrade é comentada por Patrícia da Silva Cardoso (UFPR). As outras duas resenhas tratam de títulos importantes que recentemente ganharam novas edições: Calunga, de Jorge de Lima, e Navios iluminados, de Ranulfo 
Prata, analisados respectivamente por Carlos Frederico Barrére Martin (USP) e Benito Martinez Rodriguez (UFPR).

Finalmente, a seção de documentos traz alguns textos críticos que foram fundamentais para a definição do romance social durante a década de 30, além de dois artigos, tão interessantes quanto desconhecidos, de Dyonélio Machado. O leitor tem ainda em mãos um pequeno conjunto de capas de livros desenhadas pelo homem que deu expressão visual ao romance de 30, Santa Rosa, e também duas capas criadas pelo romancista Cornélio Penna.

Ivan Marques (USP)

Luís Bueno (UFPR) 